Leszek Teusz ${ }^{1}$

Uniwersytet im. Adama Mickiewicza w Poznaniu

DOI: https://doi.org/10.26881/jsr.2021.16.15

\title{
ETOS RYCERSKI \\ W SZESNASTOWIECZNYCH KAZANIACH NA POGRZEBY KRÓLÓW POLSKI
}

Kultura rycerska, zasady i obyczaje etosu rycerskiego, zawarty w nich system wartości oraz ideał osobowy (zob.: Piekarczyk 1975; Potkowski 1978; Iwańczak 1983, 1984, 1985; Duby 1986; Runciman 1987; Clare 1992; Cardini 1996; Peltz, Dudek 1997; Morrison 1997; Flori 1999; Mundy 2001; Kusiak 2002; Barber 2003; Nicholson 2005; Keen 2014) odcisnęły ślad również na kulturze polskiej (zob.: Bieniak 1973; Nadolski 1979; Klubówna 1979; Kuczyński 1980; Kuczyński 1992; Bogucki 1996; Dalewski 1997; Skurzyński 2000; Świderska 2001). Rozkwit związanych z rycerstwem kultury i obyczaju nastąpił przede wszystkim w czasach pierwszych Jagiellonów, w wiekach XIV i XV, kiedy było już ono w pełni wyodrębnionym stanem. Następujący potem stopniowo kryzys duchowości i obyczajowości rycerskiej wyznaczały między innymi przemiany gospodarcze, w których wyniku

szlachetnie urodzeni albo w szybkim tempie pauperyzowali się, albo ciągnęli duże zyski z innej niż w latach poprzednich działalności. W Polsce od lat czterdziestych XV wieku, tj. od czasu powstania koniunktury na eksport zboża do Europy Zachodniej, szlachta zainteresowała się handlem zagranicznym i dążyła do wzrostu produkcyjności własnych majątków, powiększała swój folwark, zagospodarowywała nieużytki, zwiększała wymiar chłopskich obciążeń. Rycerze stawali się ziemianami zainteresowanymi nie poszukiwaniem sławy, lecz bogaceniem się na handlu towarami rolnymi i leśnymi (Piwowarczyk 1998, s. 228).

Do tego doszły zmiany dokonujące się w sztuce militarnej, strategii prowadzenia wojen, których konsekwencją był m.in. upadek znaczenia ciężkozbrojnej jazdy. Dawne ,rycerskie umiejętności - jazda konna, władanie mieczem i kopią były dalece niewystarczające do wygrywania bitew i zdobywania zamków. [...] Równocześnie następował proces, który można by określić «komercjalizacją»

\footnotetext{
${ }^{1}$ teusz@amu.edu.pl,https://orcid.org/0000-0001-7218-330X
} 
wojny” (Piwowarczyk 1998, s. 229-230). Zaczęła ona być dobrze płatnym ,interesem”, zajęciem dla wyspecjalizowanych ,zawodowców”, gotowych w każdej chwili do wynajęcia w roli najemników i zaciężnych. Towarzyszyły temu także przeobrażenia dotyczące samego przebiegu kampanii wojennych. Wiązały się one z coraz większą rolą przy oblężeniach i zdobywaniu obozów nieprzyjaciela, przypadającą oddziałom piechoty, oraz wzrastającym znaczeniem artylerii. To one w dużej mierze zadecydowały ostatecznie o utracie przez rycerstwo militarnej pozycji.

Rola miecza, atrybutu rycerza, odchodziła stopniowo w przeszłość (Piwowarczyk 1998, s. 231). Przemiany społeczne kształtowały ideologię szlachecką, podkreślającą wielką wartość ziemiańskiej egzystencji, będącą pochwałą życia, w którym dominowały przyjemności i pożytki z obcowania ze światem natury i uprawą roli; którego rytm wyznaczają stabilność i bezpieczeństwo. Adam Karpiński, charakteryzując staropolską poezję ideałów ziemiańskich, zauważa:

Ziemianin-gospodarz, postać będąca rozwinięciem toposu człowieka-oracza, pozostaje uosobieniem stabilizacji. Dążeniu do stabilizacji, jej ciągłemu potwierdzaniu służą przede wszystkim podkreślanie niechęci do kondycji rycerskiej i wykazywanie pożytków zapobiegliwości gospodarskiej. Z punktu widzenia konstrukcji bohatera-rycerza te znamiona ziemianina składają się na antywzorzec osobowy, z punktu widzenia zaś ideałów ziemiańskich im właśnie, nierycerskości i zapobiegliwości rolniczej przypada rola budowania ziemiańskiego szczęścia, one pozwalają nadal przeciwstawiać ziemianina człowiekowi daremnie poszukującemu (Karpiński 1983, s. 54)².

W sposób szczególny owo programowe credo, apologia zgodnego z naturą żywota wiejskiego, akcentująca jego wyższość nad żołnierskimi losami oraz chwaląca związaną z wiejską Arkadią, szczęśliwą egzystencję, która źródłami swymi sięgała utworów Teokryta i Wergiliusza a także Horacjańskiej epody Beatus ille qui proculnegotiis, znalazła wyraz w gatunku, jakim było votum ziemiańskie. Stwierdzając, że „takie votum [...] począwszy od pierwszego ćwierćwiecza XVII stulecia, miał w swoim dorobku niemal każdy z liczących

${ }^{2}$ Autor zauważa, że obecna w polskiej poezji ziemiańskiej pochwała prostego, miernego żywota, które toczy się z dala od dworów i miast oraz rycerskich przygód, bliska była przejętemu z literatury antycznej horacjańskiemu ideałowi aurea mediocritas, występującemu w licznych utworach europejskich autorów. Jako przykład podaje cytowane przez Johana Huizingę fragmenty poematu Filipa de Vitry Le Dit de Franc Gotier oraz ballad Eustachego Deschampa: Odtad na przyszłość pragnę prowadzić / Życie umiaru, to moje zadanie, / Wojnę porzucić i orać rolę: / Wojnę prowadzić - oto przekleństwo (Karpiński 1983, s. 12). Zob. także: Gruchała, Grzeszczuk 1988. 
się poetów polskich" (Pelc 1972, s. 148), Janusz Pelc przywołuje Zbigniewa Morsztyna, jednego z twórców, którego „droga do «Arkadii» wiejskiej wiodła poprzez służbę żołnierską, poprzez smak klęski i niewoli i poprzez służbę dworską" (Pelc 1972, s. 149):

Ale do roli wracam się od wojny,

Czy nie lepiejże żywot wieść spokojny?

Nie lepszaż dola drugiego pasterza

Niźli rycerza?

Niech każdy przyzna, czy nie droższa złota

Wszytkie godziny takiego żywota?

Gdy pańskie dwory, wysokie kominy,

Ich gęste dymy wzgardzę

(cyt. za: Pelc 1972, s. 149).

Styl życia szlachcica - ziemianina, przekonanie, że vita beata to vita rustica, aktualizował wzór, ideał dobrego gospodarza, Rejowego „człowieka poczciwego" (Rej 1979)33, hołdującego życiu spokojnemu, oddalonemu od trosk i niepokojów Marsowego pola i związanych z nim przygód (zob.: Tazbir 1983, 1976, 1986; Zajączkowski 1993). Jego postawę wobec świata wyznaczał moralny ład, ziemiański etos, którego wyrazem stała się stoicko rozumiana cnota.

Jak zauważa Alina Nowicka-Jeżowa (2009-2011, s. 261), „literatura ziemiańska odzwierciedla ideę pacyfistyczną, która [...] wywodziła się z renesansowego humanizmu i kształtowała świecki model życia wolnego i szczęśliwego". Jednak stopniowe przekształcanie się rycerstwa w stan szlachecki, stopione z „barokową ideą wojny" (Nowicka-Jeżowa 2009-2011, s. 262) spowodowało, że wartości przypisane etosowi rycerskiemu stały się podstawą kultury sarmackiej. To w sarmackim świecie zaznaczyły swoją obecność liczne jego kontynuacje i nawiązania, w formie i treści bliskie rycerskiej obyczajowości i rycerskiemu duchowi (Buczek 1978; zob. także: Opaliński 1995; Borowski 2001; Baczewski 2009). Idea rycerska stała się dominującym składnikiem sarmackiej wizji świata i obecnego w niej systemu wartości. Szczególnego znaczenia nabierała bohaterska służba sarmackiego żołnierza względem ojczyzny - służba okupiona niejednokrotnie heroiczną śmiercią w obronie zasad sarmackiego kodeksu rycerskich

${ }^{3}$ Składający się z trzech ksiąg prozaiczny traktat parenetyczny, jakim jest Żywot człowieka poczciwego, stanowi najobszerniejszą część Źwierciadła, dzieła opublikowanego przez autora w r. 1567/1568. W utworze tym przedstawił Rej ideał szlachcica - ziemianina, którego życie ukazuje w dwóch porządkach: od narodzin poprzez wiek dojrzały do starości oraz na planie pór roku (zob.: Dziechcińska 1969; Weintraub 1969; Wichowa 2005; Kowalski 2004). Szerzej o ideologii ziemiańskiej szlachty polskiej: Karpiński 1983; Gruchała, Grzeszczuk 1988. 
wartości (Nowicka-Jeżowa 2009-2011, s. 262 i nast.; zob. także: Pelc 1970; Ocieczek, Mazurek 2001; Ocieczek, Walińska 2001; Borowski 2001). Nastąpiło też swego rodzaju stopienie się rycerskiego i chrześcijańskiego etosu, co prowadziło do schrystianizowania motywu świeckiej sławy. „Prawy rycerz umierający dla ojczyzny, dla chwały sarmackiego oręża i własnego rodu, a także dla sławy osobistej, stawał się godny obcowania z Bogiem" (Nowicka-Jeżowa 2009-2011, s. 273; zob. także: Tazbir 1987; Nowicka-Jeżowa 1992; Lenart 2009). Wiara oświetla curricula żołnierzy sarmackich, detronizując z piedestału renesansową fortunę i wpisując ich losy w metafizyczny wymiar (Nowicka-Jeżowa 2009-2011, s. 277; zob. także: Lenart 2008).

Świadectwem potwierdzającym wagę i trwałość rycerskiego etosu były m.in. kazania pogrzebowe z przełomu XVI i XVII w. Kazanie pogrzebowe, należące do antycznej spuścizny kulturowej, łączące w sobie zasady genus demnostrativum, artes praedicandi oraz reguły mowy pogrzebowej wypracowane przez Menandrosa i Polibiusza, podjęte i rozwinięte przez tradycję patrystyczną, przybierało charakter laudatio funebris i stało się powtarzającym się, stałym elementem obrzędowości i obyczajowości funeralnej, realizując wymogi kompozycyjne antycznej oracji (Platt 1992, s. 157) ${ }^{4}$. Te ostatnie poddane zostały w kontekście chrześcijańskim pewnym modyfikacjom. Zasadniczo jednak kazanie, w tym jedna z jego odmian, jaką było kazanie pogrzebowe, składało się ze stałych części: exordium, narratio, argumentatio, refutatio i epilogus (Platt 1992, s. 157). Wskazują one swoje głębokie źródłowe powiązanie z retoryką starożytną, z greckim oratorstwem okolicznościowym, jakim były mowy pogrzebowe (Skwara 1999, s. 296-298).

Celem artykułu jest ukazanie obecności etosu rycerskiego w kazaniach na pogrzeby królewskie w XVI-wiecznej Polsce. Były to, jak się przypuszcza, pierwsze drukowane kazania pogrzebowe, wygłoszone przez znakomitych kaznodziejów swoich czasów, które po opublikowaniu rozpoczynają dzieje gatun$\mathrm{ku}$, jakim jest mowa pogrzebowa, w języku polskim ${ }^{5}$. Przedmiotem uwagi staną

${ }^{4}$ Warto odnotować najważniejsze opracowania dotyczące kazań pogrzebowych. Są one przedmiotem zainteresowań badaczy historii sztuki (Chrościcki 1968, 1974; Zieliński 2004), historii wymowy i historii kaznodziejstwa (Brzozowski 1975; Mecherzyński 1856; Panuś 2001; Pelczar 1896; Szpaderski 1856), a także historii i historii literatury (Baczewski 2002; Barłowska 2008; Czarliński, Giżycki 2007; Jarczykowa 1994; Kosman 1972; Nowicka-Struska 2008; Pawlak 2005; Piersiak 1986; Popiołek 2004; Sitkowa 1994; Skwara 1999, 2002, 2004, 2008, 2009; Trawicka 2001; Żrałko 2005).

${ }^{5}$ D. Platt (1992), opracowując dzieje kazań pogrzebowych z przełomu XVI i XVII wieku, pisze: „Prawdopodobnie pierwszym kaznodzieją, który wygłosił kazanie pogrzebowe w języku polskim, był Stanisław ze Skarbimierza [zob. Stanisław ze Skarbimierza 2014]. Wygłoszone podczas pogrzebu królowej Jadwigi w r. 1399, zostało jednak zapisane po łacinie. Podobnie zdarzyło się z kazaniem na pogrzeb Władysława Jagiełły (1434) 
się dwa kazania: kazanie ks. Marcina Białobrzeskiego, wygłoszone w roku 1572 na pogrzebie Zygmunta Augusta, wydane jako edycja samodzielna w 1574 r., a następnie w „Postylli” tegoż kaznodziei w 1581 r., oraz pochodzące z 1586 r. kazanie ks. Hieronima Powodowskiego z pogrzebu Stefana Batorego, wydane W $1588 \mathrm{r}$.

Śmierć królów - będąca doskonałym tematem dydaktycznym, potwierdzającym, jak złudne i nietrwałe jest ludzkie, ziemskie szczęście (Platt 1992, s. 59) znajduje w analizowanych mowach pogrzebowych przede wszystkim wyraz w ukazaniu wielkości straty poprzez użycie różnych formuł lamentacyjnych. Wpisują się one w nadrzędny, patetycznie konstruowany topos dramatycznej, nieodwołalnej odmiany losów. Zestawienie żywy - zmarly osiągane jest przez liczne porównania i kontrasty. W kazaniu na pogrzeb Stefana Batorego autor pokazuje, jak wjazd tryumfalny króla zamienia się w obrzęd pogrzebowy, jak wszystkie symbole władzy królewskiej oraz rycerskiej dzielności i męstwa odsłaniają w godzinie śmierci żałosną, wanitatywną postać:

Korona królewska pozorna, śliczną głowę jego opadłszy, czarnym a żałobnym stolcem jako osierociała wdowa się osadziła. Sceptrum i miecz mężną jego ręką niekiedy wynoszone, teraz na żałobnym łożu, jakoby też z nim umierając, poległy. Jabłko złote z ręki wypadłszy, już nie okrąg fortunnego panowania jego, ale właśnie przewrotnego szczęścia i niepewnego żywota ludzkiego obłudne zatoczenie wyraża. Nuż poczty, barwy, proporce i insze pompy i przyprawy żałość jakąś nową, nie tylko nasze, ale jakoby wszystkich rzeczy, które przed tym, temu panu po woli były, przed oczy nam wystawiają. [...] Dziwna a żałosna rzecz (Powodowski 2014, s. 203-204).

Składnikiem etosu rycerskiego było dobre urodzenie, bycie ogniwem szczytnego, genealogicznego drzewa. W każdym kazaniu pogrzebowym następowała zatem pochwała rodu. „Zarówno reguły genus demonstrativum, jak i normy patetikos epitafios nakazywały rozpoczynanie pochwały od przypomnienia przodków" (Platt 1992, s. 60).

Pawła z Zatora. Od tego momentu kazania pogrzebowe najczęściej pojawiały się w dwóch wersjach językowych, jak to było przy pogrzebie Zygmunta Starego (1548). Mówiło wówczas wielu mówców, zarówno świeckich, jak i duchownych. Po polsku przemawiał biskup Samuel Maciejowski, ale wyrażono z tego powodu niezadowolenie; dlatego też jeszcze w tym samym roku autor opublikował wersję łacińską. Po polsku przemawiał także Leonard Słonczewski, którego kazanie nie dochowało się do naszych czasów. Najbardziej znanym kazaniem z tego pogrzebu jest Funebris oratio Stanisława Orzechowskiego, wygłoszone i zapisane po łacinie. W czasie tego pogrzebu przemawiali także po łacinie Marcin Kromer i Maciej Frank" (Platt 1992, s. 7-8). 
W kazaniu na pogrzebie Zygmunta Augusta przedstawienie przodków ma bardzo rozbudowaną postać:

Narodził się był król a pan nasz Zygmunt August z ojca Zygmunta, tym imieniem pierwszego króla polskiego, dobrego, cnotliwego, świętego króla, ojca prawego ojczyzny naszej i królestwa tego. Który Zygmunt świętej pamięci, król nasz polski, urodził się był z ojca Kazimierza, Jagiełłowego syna. A z matki Elżbiety, dziewki Wojciecha z domu zacnego rakuskiego, cesarza naonczas chrześcijańskiego a króla węgierskiego i czeskiego. $Z$ takich zacnych rodziców ojca, tak zacnego dziada po ojcu swym, także i babkę miał Zygmunt August, ten umarły król i pan nasz. [...] Zacność matki jego zaś jest taka. Matka była Bona, Jana Galeacego Sforcyjej, książęcia mediolańskiego, a Izabelle, która ród swój z aragońskich, sykulskich i z neapolitańskich królów wiodła. [...] Z tak zacnych rodziców narodził się był nam król Zygmunt August, lata Pańskiego 1520. O domu i zacności Jagiełła króla, abych łaskom waszym miał powiadać, nic bym nie czynił, jedno kronikę czytał, bo żaden takim gościem w Polszcze, a iż mam rzec we wszytkiej Sarmacyjej nie jest, który by tego nie wiedział, co za naród Jagiełłów, jako święty, zacny, waleczny, i jako wiele dobrego królestwu temu uczynił. Ci przyłączyli wszytkę ojczyznę swą do Polski, Prusy zwycięstwy swoimi skrócili, poddanymi uczynili koronnymi, ci Tatary, Wołochy, Moskwę i wszystki nieprzyjacioły Korony tej zwycięstwy swymi skrócili... [...] Ci prawdziwi miłośnicy byli wiary chrześcijańskiej świadczy Wielkie Ksiestwo Litewskie, które Władysław Jagiełło, sam apostołem ich będąc, nawrócił do Pana Chrystusa i pokrzcił.; świadczą to polskie kościoły, klasztory i szpitale od nich zbudowane i insze dawne, które wielkim nadanim, ochędostwem kościelnym, wielkimi dobrodziejstwy ozdobili i nadali. $\mathrm{Z}$ tego tedy Jagiełłowego domu ostatni ten Jagiełło narodził się był tak zacnie wychowan jako jedyny syn wielkiego króla, na panowanie tak wielkiego królestwa wszytkim potrzebny (Białobrzeski 2014, s. 88).

Ks. Hieronim Powodowski z kolei, w kazaniu na pogrzebie króla Stefana Batorego, stwierdza: „Kto kroniki dobrze przewiedzi, najdzie w nich familiją Batorów, z których pan nasz zmarły poszedł, znacznie zaleconą, nie tylko od mężstwa, ale także od zacnego rodu starodawności" (Powodowski 2014, s. 205);

[...] ta familija Batorów tak jest od Boga i od narodu swego przez osobliwe cnoty uczczona, iż w krótkim czasie dobrze znaczna została, nie tylko w siedmiogrodzkim, ale też w najwyższym apostolskim senacie. Nie tylko w stolicy zwierzchniej domowego już to po trzykroć panowania, ale też na zacną stolice królewską w przeszłym panie naszym wywyższenia" (Powodowski 2014, s. 205-206). 
Wskazanie dobrego, szlachetnego urodzenia stanowi rozwinięcie laudacji zalet króla Stefana Batorego poprzez nawiązanie do toposu dobrych przodków, których cnotom władca starał się dorównać: „Z dobrego tedy drzewa, jaki owoc, dalej uważajmy" (Powodowski 2014, s. 206). Asekurując się, poprzez wykorzystanie retorycznej topiki, że ,przez żywota jego wszech cnót napełnionego, [...] którego cnoty a dzielność już przed tym są wszem jak miarz światu rozgłoszone" (Powodowski 2014, s. 202), zadanie, którego się podejmuje mówca - oddanie pochwały króla - „chociaby wszystko ciało i członki obróciły się w język, tedy takiej chwały według potrzeby wypowiedzieć, nie przemogą" (Powodowski 2014, s. 202) - przystępuje do przedstawienia postaci zmarłego. Tłumacząc, że „w królu Stefanie $[. .$. ] były wszystkie cnoty tak zniesione, jako w jedną sztukę malarską wiele inszych obrazów" (Powodowski 2014, s. 205), wybiera dla ukazania zmarłego władcy siedem cnót. Zgromadzenie cnót i służących ich eksplikacji przykładów (congeries) oraz porównań (comparatio) staje się podstawową amplifikacyjną strategią elocutio.

Najważniejszą z cnót jest religijność, która podporządkowana została stateczności. Batory do końca życia pozostał wierny katolickiej wierze, a prowadzone przez niego wojny powodowały „chwały Bożej rozmnożenie”. Odnosząc się do stateczności, odwołuje się kaznodzieja do Biblii: „W młodości tego pana najdowała się taka stateczność, jaką Pismo święte zaleca w Samuelu” (Powodowski 2014, s. 206). Charakteryzująca ideał rycerski pobożność objawiała się u króla uczestnictwem we Mszy świętej, „bez której słuchania na każdy dzień, okrom gwałtownej przekazy, spraw żadnych nie zaczynał”, oraz tym, że „zamykał się na osobliwej modlitwie, w której krzyżem leżąc, sprawy swe i koronne, zwłaszcza w potrzebach wojennych, Bogu z płaczem zalecał. A i do inszych modlitw, postów i nabożeństw pospolitych, gdy co wielkiego nie przeszkodziło, nikomu się uprzedzić nie dał" (Powodowski 2014, s. 207).

W kazaniu na pogrzeb Zygmunta Augusta pochwała cnoty religijności następuje przy ukazaniu momentu śmierci, którego przedstawienie kończy mowę kaznodziei. Takie zakończenie jest szczególnie istotne, ponieważ rekapituluje, zwieńcza niejako wyliczone wcześniej, wszystkie zalety zmarłego:

Gdy już widział, że się z tym światem rozstać miał, zostawiwszy nam jedność, pokój i miłość za upominki, wiedząc się być człowiekiem, który Pana Boga częstokroć gniewał, począł z nieprawości swych przed Panem Bogiem się uskarżać, a Jego o łaskawe miłosierdzie prosić, aby nie według sprawiedliwości swej, ale według miłosierdzia raczył go sądzić. Wiedząc tedy w Kościele chrześcijańskim być klucze rozwiązania i zawiązania grzechów, kazał sobie po sługę Kościoła Bożego kapłana, którego wziął za świadka sumnienia swego, przed Panem Bogiem uniżył serce i sumnienie swe. Wyznał wszytki grzechy i nieprawości swe, których się przed tymże kapłanem jako posłańcem Bożym i namiestnikiem apostolskim 
spowiadał i z nich z wzywaniem Imienia Bożego i z błogosławieństwem jego rozgrzeszenie wziął [...] przyjął prawdziwe a istotne ciało Pańskie z wielkim nabożeństwem. A wiedząc, że nie tylo umysłem, sercem i wnętrznościami swymi grzeszył przeciwko Panu a stworzycielowi swemu, ale też i zmysłami cielesnymi. Chciał też, aby te członki, które niekiedy k woli czartu i światu obracał, Panu Bogu poświęcone i poślubione były, przeto z błogosławieństwem i z modlitwami, aby Pan Bóg członki wszytki jego sobie miłymi uczynił, olejem świętym ony pomazać dał i tak już prawie wszytek Panu Bogu się poruczywszy, umarł jest. Umarł jest król, pan, dobrodziej, obrońca nas wszytkich (Białobrzeski 2014, s. 97).

Akcentowanie religijności na szczycie hierarchii cnót to stały motyw laudacji. Pobożność, związana w życiu z regularnymi praktykami religijnymi, stawała się w momencie śmierci swego rodzaju „bramą”, otwierającą ziemską egzystencję na wymiar eschatologicznej pełni.

Drugą cnotą, którą z kolei wyróżnia autor kazania przy pogrzebie Stefana Batorego, jest „miłość uprzejma ku Rzeczypospolitej naszej, którą pokazował, jako dobry pasterz przeciw owcom swym, jako uprzejmy oblubieniec przeciw oblubienicy swej i na koniec jako zdrowa a roztropna głowa przeciw własnemu ciału swemu” (Powodowski 2014, s. 207). Jak zaznacza kaznodzieja, „po Bogu i chwale a łasce Jego to u niego najprzedniejsze i najusilniejsze staranie było, jakoby państwa i poddane swe w całości, w pokoju postronnym, w bezpieczeństwie i rządzie domowym zachował" (Powodowski 2014, s. 207). Z miłości ku ojczyźnie wynikało uczestnictwo w zjazdach, sejmach, a także w ekspedycjach wojennych. W tym kontekście akcentuje Powodowski przede wszystkim męstwo i odwagę, dwie oznaki waleczności prawdziwego rycerza, które, połączone z wiernością i lojalnością, były konieczne dla wypełniania obowiązku służby publicznej. Ich brak, posądzenie o tchórzostwo, był przecież najcięższym zarzutem o zdradę rycerskiego kodeksu (Ossowska 2000, s. 70). Kaznodzieja, wyliczając zalety króla, opowiada o jego czynach: wypuszczeniu jeńców z niewoli, przymierzu z Turkami, budowaniu nowych zamków na granicy. „Jego wielkie męstwo, serce i biegłość w rzeczach rycerskich niewyrównana" - stwierdza autor przemowy; „tego pana sławą jakmiąrz pod gwiazdy wyniosła” (Powodowski 2014, s. 209). Mówca dokonuje pochwały Batorego, zestawiając jego osobę z Merkurym Trismegistosem, tj. trojako najświętszym, mówiąc: „Tedy my też Stefana naszego możemy nazwać, iż był Principium religiosissimus, Regum sapientissimus, Imperator umfortissimus, to jest gdyż książęta pobożnością, króle mądrością, hetmany mężnością czasu swego przewysszał" (Powodowski 2014, s. 212).

Cnotą, w której - jak mówi kaznodzieja - „król Stefan przodkował” (Powodowski 2014, s. 208), była sprawiedliwość. Przywołując słowa św. Augustyna: „Odjąwszy sprawiedliwość, cóż są królestwa jeno wielkie rozbójstwa” (Powo- 
dowski 2014, s. 208) oraz porównując władcę z biblijnym Salomonem, stwierdza, że Pan Bóg ,natchnął go tak dziwnym domysłem sprawiedliwych wyroków, iż wielkie wykręty i kalumnie, jakich się w sadach naszych naniosło, od nich jako ogień od wody gasnąć i dymem wychodzić musiały" (Powodowski 2014, s. 208). Jak ważną cnotą była królewska sprawiedliwość, podkreśla kaznodzieja sądem ogólnym, że ,jaki jest ten, kto lud sądzi, tacy też są urzędnicy jego, i jaki jest sprawca rzeczypospolitej, takimi też są mieszkający w niej” (Powodowski 2014, s. 208). Umiłowanie sprawiedliwości, połączone z miłosiernym darowaniem kar, ilustruje Powodowski następującym przykładem:

rozlanie krwie, choć też i winnej, barzo mu było przykre, jenoż taki taniec, kto ji zacznie, bez tego być nie może i takowe koła rozbieżane zajątrzonego rycerstwa, hamować bywa trudno. Świadkami tego może być wiele więźniów, których gdy bezpiecznie mógł, wiele wolno, czasem z podarowaniem wypuszczał. Owa może się mu przystosować ona pochwała z Pisma św.: Aperuit os suumsapintiae, et lex clementiae in lingua eius, usta jego były otworzyste mądrością, a ludzkość jakby prawem ugruntowana w języku jego (Powodowski 2014, s. 209).

Maria Ossowska, charakteryzując średniowiecznego rycerza, pisze:

podczas gdy odwaga służyła rycerzowi w wykonywaniu jego zawodu, hojność, której się po nim spodziewano i którą uważano za nierozłączny atrybut szlachetnego urodzenia, służyła ludziom od niego zależnym, a przede wszystkim tym, którzy na dworach sławili wielkie czyny rycerskie, spodziewając się dobrego poczęstunku i należytego obdarowania na dalszą drogę (Ossowska 2000, s. 71).

U Powodowskiego hojność Batorego, będącą wyrazem sprawiedliwości, wyraża „obrona dobrych i miłość przez hojne według zasług opatrowanie” (Powodowski 2014, s. 209). Kaznodzieja pochwala przy tym króla przede wszystkim za hojność roztropną, za to, że rozumiał, iż „dawne zasługi trzeba było tak nagradzać, aby się świeże, które prawie w oczu były, nie omijały, bez których potrzeby zaczęte się prowadzić mogły” (Powodowski 2014, s. 209). „Ale iż ten pan - kontynuuje - cnotę, godność, męstwo miłował i gdzie mógł wywyższał, to mu każdy prawdę znający przyznać musi” (Powodowski 2014, s. 209). Szczodrość zestawia autor kazania z pochwałą królewskiej skromności w obyczajach. Zastosowanym mechanizmem logicznym staje się w tym przypadku dowodzenie z przeciwieństwa (ex contrario) eksplikowane przez przeciwstawienie (adversa).

Rycerzowi towarzyszyło pragnienie sławy, która miała utrwalić jego imię oraz czyny. I ten wątek odnajdujemy w kazaniu chwalącym zmarłego króla Stefana Batorego: 
Imię i sława króla Stefana była tak ważna, iż nam nie tylko przymierze z Mahumetckimi pohańcami i dotrzymanie jego snadnie przychodziło. [...] A [...] się nam to wszystko zeszło nie dla jakiego podejźrzanego z tym pogaństwem zachowania, jako zazdrość niektórych z przodku udawała, ale dla postrachu męstwa polskiego przez króla Stefana jakoby wskrzeszonego. Któremu przypatrować się przyjeżdżali posłowie nieprzyjacielscy, pod postawą poselstwa zamyślonego na dwór jego królewski i do wojska, skąd sławę niepłoną gotowości polskiej panom swym donosili. [...] Tedy o tym królu mężnym może się rzec, co o Mojżeszu Pismo św. wspomina: Magnificavit eum Dominus in timore inimicorum et in verbis susi monstra placavit._Pokazał go Pan Bóg sławnym w bojaźni nieprzyjaciół i słowami swemi dzikie potwory krócił (Powodowski 2014, s. $210-211)^{6}$.

W kazaniu przy pogrzebie Zygmunta Augusta zaś czytamy:

Umarł nam król, Polacy! Ale pytasz: jaki król?” Taki, który „đługo rozkazując, fortunnie, łaskawie i sławnie” z „Jagiełłowego domu”, „ostatni nas wszytkich dobrodziej [...] nie tyran, ale łaskawy, nie okrutnik, ale miłosierny, nie popędliwy w gniewie, ale nazbyt cierpliwy, nie skąpy, ale szczodry, nie ospały, ale czujny, nie opilca, ale trzeźwi, nie głupi, ale mądry, roztropny, baczny, przyszłym wszytkim przygodom i upadkom, dowcipnie zabiegający (M. Białobrzeski 2014, s. 86).

Podkreśla następnie kaznodzieja hojność władcy:

I małesz jeszcze dobrodziejstwo uczynił wam rycerskim ludziom, że czwartą część dochodów wszystkich do skarbu pospolitego koronnego darował, sobie ją odejmując. Toć dlatego uczynił, aby za te pieniądze na granicach młodzi ludzie ślacheckich domów w sprawach rycerskich się ćwiczyli, a szkoła rycerska żeby się zawżdy mnożyła. Najazdów i szkód drapieżnych Tatarów, aby przestrzegano i strzeżono, ludźmi służebnymi na granicach, rycerstwu służbę żołnierską, żeby miano czym płacić, granice od niebezpieczeństwa aby były wyswobodzone. Nadto jeszcze, aby królestwo czasu potrzeby miało się do czego rzucić, a zgołocone od skarbu pospolitego nie było" (Białobrzeski 2014, s. 92).

${ }^{6}$ Jak objaśniają wydawcy (Panuś, Skwara 2014b, s. 239), „w Wulgacie i w przekładzie Wujka cytat ten brzmi: «magnificavit eum in timore inimicorum, et in verbis suis monstra placavit, uczynił go wielkim przez strach nieprzyjaciół i na jego słowa dziwy uśmierzył» (Ekl 45,2)". 
Chwała rycerza związana była także z czcią jego osoby i imienia, ze szczególnym „uważaniem”, którym się cieszył. Wątek ten w kazaniu na pogrzebie Zygmunta Augusta zostaje wyrażony w sposób następujący: „Takiegośmy króla mieli, który w to umiał trafić, iż go tak zacnie wielcy cesarze i królowie u siebie uważali. Bo jednak nie tylko przyjaciołom, ale i nieprzyjaciołom taką układność i szczodrobliwość pokazował, że wszyscy go wobec musieli miłować" (Białobrzeski 2014, s. 95). W kazaniu na pogrzebie Stefana Batorego wielkość chwały króla podkreślona zostaje poprzez zaakcentowanie, że śmierć stanowi jakby wywyższenie jego zasług i cnót, jest, paradoksalnie, jakby zwielokrotnieniem, pomnożeniem jego wielkości i wspaniałości: ,śmierć tego pana naszego sławy i jego, i naszej także, nie tylko z nim nie umarza, ale im dalej, to ją więcej ożywia. [...] bo iż umarł, to należy do pospolitego ludziom osłabienia; iż takim umarł, należy to do osobliwego podziwienia" (Białobrzeski 2014, s. 215). W zakończeniu kaznodzieja odwołuje się do sugestywnego, obrazowego porównania; „śmierć króla Stefana była nam tak żałosna i straszliwa jako skore podcięcie onego ślicznego drzewa, aż ku niebu wyrosłego, na którym osiadło i żywiło się wszelakie ptastwo i pod nim wszelaki źwierz miał skłonienie swoje" (Białobrzeski 2014, s. 215).

Można zauważyć, że pochwała zmarłych władców w przedstawionych kazaniach, argumenty uwypuklające ich wielkość zgodne były z tradycją teorii retorycznej, zatem silnie skonwencjonalizowane i odpowiadające regułom gatunku. Najsilniej procesowi amplifikacji i hiperbolizacji poddane zostały przede wszystkim czyny i zalety królów, natomiast pominięto elementy dotyczące ich wyglądu zewnętrznego (Platt 1992, s. 63).

Jak zauważają Kazimierz Panuś i Marek Skwara (2014a) we Wprowadzeniu do Kazań funeralnych (będących jedną z części antologii, która zawiera ponadto polskie kazania maryjne i pasyjne),

w dziejach staropolskiej kultury funeralnej uroczystości pogrzebowe poświęcone zmarłym królom pełniły ważne funkcje: były wydarzeniami politycznymi, które oddziaływały zarówno wewnątrz państwa, jaki na arenie międzynarodowej; były uroczystościami religijnymi, które stanowiły spoiwo wspólnoty katolickiej i jednocześnie pełniły funkcje propagandowe wobec innowierców, były wreszcie wydarzeniami kulturowymi (Panuś, Skwara 2014a, s. 13).

Idea wyobrażania zmarłego władcy w pogrzebowym theatrum ceremoniale (zob.: Śnieżyńska-Stolot 1975; Borkowska 1986), którego kazanie stanowiło zasadniczy element, wpisywała się w „długie trwanie” takiego przedstawienia, w bogactwo tradycji rycerskiego etosu, rycerskich wartości i wzorów w kulturze dawnej. 


\section{Bibliografia}

Baczewski S. (2002), Obraz śmierci w XVII-wiecznych polskich kazaniach pogrzebowych, „Roczniki Humanistyczne” z. 1.

Baczewski S. (2009), Szlachectwo. Studium z dziejów idei w piśmiennictwie polskim. Druga połowa XVI wieku - XVII wiek, Lublin.

Barber R. (2003), Rycerze i rycerskość, przeł. J. Kozłowski, Warszawa.

Barłowska M. (2008), Jakub Sobieski pamięci wielkiego kawalera Bartłomieja Nowodworskiego. Wraz z tekstem mowy Rzecz J.M. Pana Jakuba Sobieskiego [...] na pogrzebie sławnej pamięci Wielkiego Kawalera..., Szczecin.

Białobrzeski M. (2014), Kazanie na pogrzebie Zygmunta Augusta, w: Kazania funeralne, wyd. i oprac. K. Panuś, M. Skwara, Kraków.

Bieniak J. (1973), Rody rycerskie jako czynnik struktury społecznej w Polsce XIII-XV wieku. Uwagi problemowe, w: Polska w okresie rozdrobnienia feudalnego, red. H. Łowmiański, Wrocław 1973.

Bogucki A. (1996), Rycerz i panosza w źródłach polskich XIV i XV wieku, w: Społeczeństwo Polski średniowiecznej, red. S.K. Kuczyński, t. 7, Warszawa.

Borkowska U. (1986), Ceremoniat pogrzebowy królów polskich w XIV-XVIII wieku, w: Państwo. Kościót. Niepodległość, red. J. Skarbek, J. Ziółek, Lublin.

Borowski A. (red.) (2001), Stownik sarmatyzmu. Idee, pojęcia, symbole, Kraków.

Brzozowski M. (1975), Teoria kaznodziejstwa (w. XVI-XVIII), w: Dzieje teologii katolickiej w Polsce, red. M. Rechowicz, t. 2: Od odrodzenia do oświecenia, Lublin.

Buczek K. (1978), Prawo rycerskie i powstanie stanu szlacheckiego w Polsce, „Przegląd Historyczny” z. 1.

Cardini F. (1996), Wojownik i rycerz, w: Człowiek średniowiecza, red. J. Le Goff, przeł. M. Radożycka-Paoletti, Warszawa-Gdańsk.

Chrościcki J.A. (1968), Castris et astris. Kazania i relacje pogrzebowe jako źródła historii sztuki, „Biuletyn Historii Sztuki” nr 3.

Chrościcki J.A. (1974), Pompa funebris. Z dziejów kultury staropolskiej, Warszawa.

Clare J.D. (1992), Rycerze i ich czasy, przeł. H. Wodniczko, Londyn.

Czarliński B., Giżycki S. (2007), Książę Janusz Wiśniowiecki (1598-1636) w lubelskich kazaniach pogrzebowych, wprowadz. i oprac. M. Kuran, Lublin.

Dalewski Z. (1997), Pasowanie na rycerza książąt polskich we wcześniejszym średniowieczu. Znaczenie ideowe i polityczne, „Kwartalnik Historyczny” nr 4.

Duby G. (1986), Rycerz, kobieta i ksiadz. Matzeństwo w feudalnej Francji, przeł. B. Geremek, Warszawa.

Dziechcińska H. (1969), Szlachcic idealny w „Żywocie człowieka poczciwego”, czyli narracja perswazyjna, „Pamiętnik Literacki” z. 4. 
Flori J. (1999), Rycerstwo w średniowiecznej Francji, przeł. A. Kuryś, Warszawa.

Gruchała J., Grzeszczuk S. (oprac.) (1988), Staropolska poezja ziemiańska. Antologia, Warszawa.

Iwańczak W. (1983), Turniej rycerski w Królestwie Czeskim - próba analizy kulturowej, „Przegląd Humanistyczny” z. 1.

Iwańczak W. (1984), Pasowanie rycerskie na ziemiach czeskich - ceremonia symboliczna i instrument polityki, „Kwartalnik Historyczny” nr 2.

Iwańczak W. (1985), Tropem rycerskiej przygody. Wzorzec rycerski w piśmiennictwie czeskim XIV wieku, Warszawa.

Jarczykowa M. (1994), Literacka rama wydawnicza litewskich kazań pogrzebowych z pierwszej połowy XVII wieku, w: Barokowe przypomnienia i inne szkice historycznoliterackie, red. R. Ocieczek, M. Piechota, Katowice.

Karpiński A. (1983), Staropolska poezja ideatów ziemiańskich. Próba przekroju, Wrocław - Warszawa.

Keen M. (2014), Rycerstwo, przeł. A. Bugaj, Warszawa.

Klubówna A. (1979), Zawisza Czarny w historii i legendzie, Warszawa.

Kosman M. (1972), Litewskie kazania pogrzebowe z pierwszej połowy XVII w., „Odrodzenie i Reformacja w Polsce” t. 17.

Kowalski P. (2004), Theatrum świata wszystkiego i poćciwy gospodarz. O wizji świata pewnego siedemnastowiecznego pisarza ziemiańskiego, Kraków.

Kuczyński S.K. (1992), Turnieje rycerskie w średniowiecznej Polsce, w: Biedni i bogaci. Studia z dziejów społeczeństwa i kultury ofiarowane Bronisławowi Geremkowi w 60. rocznice urodzin, Warszawa.

Kuczyński S.M. (1980), Zawisza Czarny, Katowice.

Kusiak F. (2002), Rycerze średniowiecznej Europy tacińskiej, Warszawa.

Lenart M. (2008), ,, Miles Christianus” od Skargi do Starowolskiego, w: Humanizm polski. Długie trwanie - tradycje - współczesność (studia i materiały), red. A. Nowicka-Jeżowa, M. Cieński przy współpracy A. Pawlak, Warszawa.

Lenart M. (2009), Miles pius et iustus. Żotnierz chrześcijański katolickiej wiary w kulturze i piśmiennictwie dawnej Rzeczypospolitej (XVI-XVIII w.), Warszawa.

Mecherzyński K. (1856), Historya wymowy w Polsce, t. 2, Kraków.

Morrison C. (1997), Krucjaty, przeł. M. Kropiwnicka, Warszawa.

Mundy J.H. (2001), Europa średniowieczna 1150-1309, przeł. R. Sudó1, Warszawa.

Nadolski A. (1979), Broń i strój rycerstwa polskiego w średniowieczu, Wrocław - Warszawa.

Nicholson H. (2005), Rycerze templariusze, przeł. P. Chojnacki, Warszawa.

Nowicka-Jeżowa A. (1992), Feniks w popiołach. Uwagi o kulturze religijnej drugiej połowy XVII wieku, w: Literatura i kultura polska po „potopie”, red. B. Otwinowska, J. Pelc, B. Falęcka, Wrocław. 
Nowicka-Jeżowa A. (2009-2011), Barok polski między Europa i Sarmacja. Część pierwsza: Profile i zarysy całości, Warszawa.

Nowicka-Struska A. (2008), Ex fumo in lucem. Barokowe kaznodziejstwo Andrzeja Kochanowskiego, Lublin.

Ocieczek R., Mazurek B. (red.) (2001), Sarmackie theatrum. Tom 1: Wartości i stowa, Katowice.

Ocieczek R., Walińska M. (red.) (2001), Sarmackie theatrum. Tom 2: Idee a rzeczywistość, Katowice.

Opaliński E. (1995), Kultura polityczna szlachty polskiej w latach 1587-1652, Warszawa.

Ossowska M. (2000), Ethos rycerski i jego odmiany, Warszawa.

Panuś K. (2001), Zarys historii kaznodziejstwa w Kościele katolickim. Część druga: Kaznodziejstwo w Polsce. Od średniowiecza do baroku. Kraków.

Panuś K., Skwara M. (2014a), Wprowadzenie, w: Kazania funeralne, wyd. i oprac. K. Panuś, M. Skwara, Kraków.

Panuś K., Skwara M. (wyd. i oprac.) (2014b), Kazania funeralne, Kraków.

Pawlak W. (2005), Koncept w polskich kazaniach barokowych, Lublin.

Pelc J. (1972), Sarmatyzm a Barok, w: Problemy literatury staropolskiej, red. J. Pelc, seria 1, Wrocław.

Pelc J. (red.) (1970), Wiek XVII - Kontrreformacja-Barok. Prace z historii kultury, Wrocław.

Pelczar J. (1896), Zarys dziejów kaznodziejstwa w Kościele katolickim, cz. 2: Kaznodzieje polscy, Kraków.

Peltz W., Dudek J. (red.) (1997), Etos rycerski w Europie Środkowej i Wschodniej od X do XV wieku, Zielona Góra.

Piekarczyk S. (1975), Ethos rycerski-samookreślenie i wyróżnienie, „Kwartalnik Historyczny" nr 1.

Piersiak T. (1986), Barokowa sztuka dobrego umierania „Polska Sztuka Ludowa" nr 1-2.

Piwowarczyk D. (1998), Obyczaj rycerski w Polsce późnośredniowiecznej (XIV-XV wiek), Warszawa.

Platt D. (1992), Kazania pogrzebowe z przełomu XVI i XVII wieku. Z dziejów prozy staropolskiej, Wrocław - Warszawa.

Popiołek B. (2004), Konterfekt prawdziwy umbra fatalna malowany - wizerunek kobiety w staropolskich mowach pogrzebowych, „Studia Historyczne” z. 3-4.

Potkowski E. (1978), Rycerze w habitach, Warszawa.

Powodowski H. (2014), Na pogrzebie Stefana Wielkiego króla polskiego kazanie, w: Kazania funeralne, wyd. i oprac. K. Panuś, M. Skwara, Kraków.

Rej M. (1979), Żywot człowieka poczciwego, w: M. Rej, Wybór pism, oprac. J. Ślaski, Warszawa. 
Runciman S. (1987), Dzieje wypraw krzyżowych, przeł. J. Schwakopf, t. 1-3, Warszawa.

Sitkowa A. (1994), Wydawnicze losy „, Kazania na pogrzebie Piotra Skargi” Fabiana Birkowskiego w XVII i XVIII wieku, w: Barokowe przypomnienia i inne szkice historyczno-literackie, red. R. Ocieczek, M. Piechota, Katowice.

Skurzyński P. (2000), Rycerze polscy, Warszawa.

Skwara M. (1999), O dowodzeniu retorycznym w polskich drukowanych oracjach pogrzebowych XVII wieku, Szczecin.

Skwara M. (2002), O tytułach polskich kazań pogrzebowych z XVII wieku, w: Dzieło literackie i książka w kulturze. Studia i szkice ofiarowane Profesor Renardzie Ocieczek w czterdziestolecie pracy naukowej i dydaktycznej, Katowice.

Skwara M. (2004), Życie i twórczość Jerzego Laetusa Weselskiego. Przyczynek do dziejów braci czeskich na tle związów Polski i Niderlandów w XVII wieku wraz z tekstem kazania pogrzebowego, Szczecin.

Skwara M. (2008), Jana Zygrowiusza „,Melius...” na tle polskich drukowanych oracji pogrzebowych XVII wieku powiqzanych z Radziwitłami, Szczecin.

Skwara M. (2009), Polskie drukowane oracje pogrzebowe XVII wieku. Bibliografia, Gdańsk.

Stanisław ze Skarbimierza (2014), Kazanie o życiu i śmierci Królowej Jadwigi, w: Kazania funeralne, wyd. i oprac. K. Panuś, M. Skwara, Kraków.

Szpaderski J. (1856), O zasadach wymowy, t. 1, Kraków.

Śnieżyńska-Stolot E. (1975), Dworski ceremoniał pogrzebowy królów polskich w XIV wieku, w: Sztuka i ideologia XIV wieku. Materiaty sympozjum Komitetu Nauk o Sztuce Polskiej Akademii Nauk, Warszawa 29 i 30 listopada 1973, red. P. Skubiszewski, Warszawa.

Świderska U. (2001), Kultura rycerska w średniowiecznej Polsce, Zielona Góra.

Tazbir J. (1976), Wzorce osobowe szlachty polskiej w XVII wieku, „Kwartalnik Historyczny" 88.

Tazbir J. (1983), Kultura szlachecka w Polsce. Rozkwit - Upadek-Relikty, Warszawa.

Tazbir J. (1986), Wzorce osobowe szlachty, w: J. Tazbir, Szlaki kultury polskiej, Warszawa.

Tazbir J. (1987), Sarmatyzacja potrydenckiego katolicyzmu, w: J. Tazbir, Szlachta i teologowie. Studia z dziejów polskiej kontrreformacji, Warszawa.

Trawicka Z. (2001), Mowy weselne i pogrzebowe Jakuba Sobieskiego, w: Wesela, chrzciny i pogrzeby w XVI-XVIII wieku. Kultura życia i śmierci, red. H. Suchojad, Warszawa.

Weintraub W. (1969), Paradoksy poćciwości Reja, „Pamiętnik Literacki” z. 4.

Wichowa M. (2005), ,Żywot czlowieka poczciwego” Mikotaja Reja jako przykład renesansowego piśmiennictwa ziemiańskiego, w: Mikołaj Rej z Nagłowic $w$ pięćsetna rocznicę urodzin, red. W. Kowalski, Kielce. 
Zajączkowski A. (1993), Szlachta polska. Kultura i struktura, Warszawa.

Zieliński T. (2004), Kazania pogrzebowe w konwencji sarmackiej pompae funebre, w: Od liryki do retoryki. $W$ kręgu stowa, literatury i kultury. Prace ofiarowane profesorom Jadwidze i Edmundowi Kotarskim, red. I. Kadulska, R. Grześkowiak, Gdańsk 2004.

Żrałko D. (2005), Biografia Fabiana Birkowskiego w świetle kazania pogrzebowego Adama Makowskiego i badań archiwalnych, „Pamiętnik Literacki” z. 2.

\section{Streszczenie}

\section{Etos rycerski w szesnastowiecznych kazaniach na pogrzeby królów Polski}

Przedmiotem artykułu jest ukazanie obecności etosu rycerskiego w XVI-wiecznych kazaniach na pogrzeby królów Polski: Zygmunta Augusta i Stefana Batorego. Prezentacja oraz analiza fragmentów mów pogrzebowych ks. Marcina Białobrzeskiego i ks. Hieronima Powodowskiego z jednej strony ukazuje żywotność idei związanych z obrazem i cechami rycerza, z drugiej - dokumentuje aktualizowaną w XVI w. strategię konstruowania topiki pochwalnej zmarłego władcy w jej powiązaniu z tradycją starożytnej retoryki oraz z wymogami kompozycyjnymi antycznej oracji pogrzebowej. Kontekstem dla prowadzonych rozważań jest usytuowanie rycerskich wartości w perspektywie przekształcania się rycerstwa w stan szlachecki oraz dokonującej się ich transformacji w sarmackiej kulturze i sarmackiej wizji świata oraz „barokowej idei wojny”.

Słowa kluczowe: etos rycerski, kazanie, pogrzeb, król, Polska, XVI wiek

\section{Summary \\ Chivalric ethos in $16^{\text {th }}$ century sermons for the funerals of kings of Poland}

The subject of the article is to show the presence of the chivalric ethos in $16^{\text {th }}$ century sermons for the funerals of the kings of Poland: Sigismund Augustus and Stephen Báthory. The presentation and analysis of fragments of funeral speeches by Fr. Marcin Białobrzeski and Fr. Hieronim Powodowski shows, on the one hand, the vitality of the ideas related to the image and features of the knight, and on the other - it documents the strategy, updated in the sixteenth century, of constructing the topoi in eulogies of deceased rulers in connection with the tradition of ancient rhetoric and the compositional requirements of the ancient funeral oration. The context for the considerations is the location of chivalric values 
in the perspective of the transformation of knights into the noble class and the transformation of these values in Sarmatian culture and in the Sarmatian vision of the world as well as the "baroque idea of war".

Keywords: chivalric ethos, sermon, funeral, king, Poland, $16^{\text {th }}$ century 